\title{
REKONSTRUKSI POLITIK EGALITARIANISME BANGSA PERSPEKTIF MODEL NEGARA MADINAH
}

\author{
M. Sidi Ritaudin \\ IAIN Raden Intan Lampung \\ penahoo_sidi@yahoo.co.id
}

\begin{abstract}
Abstrak
Hingga saat ini kondisi perpolitikan bangsa belum bisa menampilkan bentuk yang harmonis antara pemerintah dan rakyat. Meskipun pasca revormasi pemerintah tidak lagi mengkooptasi kekuasaan dan mengontrol partisipasi rakyat, namun euphoria demokrasi belum mampu menjamin keadilan dan kesejahteraan rakyat. Hal itu lebih dikarenakan bangsa ini belum mampu mengembangkan tatanan politik yang egalitarianistis. Tulisan ini menelaah sistem pemerintahan Negara Madinah yang dipimpin Nabi Saw., sebagai model untuk memasuki pentas politik yang demokratis dan egaliter di Indonesia. Praktik politik di Negara Madinah, merupakan model pembangunan politik egalitarianisme yang sangat kondusif bagi program pemanusiaan manusia dalam Negara dan pemerintahan. Tatanan politik yang egalitarian kala itu mencerminkan idealisme politik Islam yang didasarkan kepada prinsip-prinsip dasar politik Islam yaitu: al-'adl, al-musāwāh, dan syūrā. Prinsip kesetaraan atau persamaan sesama manusia di depan hukum dan peradilan yang diterapkan oleh nabi terbukti memberikan dampak sosial-politik yang signifikan bagi upaya penegakan hukum. Penerapan prinsip-prinsip ini di Indonesia sama sekali tidak akan mengancam kesatuan nasional Indonesia. Bahkan sebaliknya, ia justru akan memberikan nilai positif dan kondusif bagi tercapainya cita-cita politik nasional..
\end{abstract}

\section{Abstract}

THE RECONSTRUCTION OF EGALITARIAN POLITICS: A Model From The Perspective Of Madinah State. Up to now, the national political condition has not been able to reveal harmonious relationship between the government and the people. Although after the Reform, the government no longer coopt the power and control the people, but the euphoria of democracy is still unable to ensure justice and public welfare. The main cause of such 
unfavorable condition is due to the fact that this country has not been able to develop an egalitarian political order. This paper explores the government system of the Medina state during the Prophet era, as a model to create a democratic and egalitarian politics in Indonesia. The political practices in the State of Medina can be viewed as a model of egalitarian politics that is very conducive to develop humanistic nuances in the state and government spheres. Egalitarian political order of the days reflected the political ideals of Islam based on the basic principles of political Islam, namely: al-'adl, al-MuSaw.ah, and al-Shura. The principle of equality before the law and justice wich was applied by the prophet proved to provide socio-political impacts and significant for law enforcement efforts. The application of these principles in Indonesia absolutely will not threaten national unity of Indonesia. On the contrary, it will give positive values and is conducive to the achievement of national political ideals..

Kata Kunci : Negara Madinah; Egalitarianisme; Demokrasi; Keadilan

\section{A. Pendahuluan}

Suatu hal yang sangat fenomenal dewasa ini adalah, semakin banyak pakar (keilmuan) di bidang hukum, realitas hukum semakin semraut, semakin banyak pakar (keilmuan) di bidang politik, kondisi perpolitikan semakin runyam, semakin banyak pakar ekonomi, kondisi keuangan bertambah kacau. Apa yang salah dengan hal demikian? Tentu saja jawabannya tidak sesederhana membalikkan telapak tangan, jawaban atas pertanyaan tersebut pasti akan beragam, tergantung dalam perspektif apa ia menjawab, yang jelas pertanyaan tersebut meniscayakan untuk mencari pola baru tentang berbagai segi kehidupan yang semakin rasional, demokratis dan egaliter. Upaya melakukan reorientasi wawasan dan sikap sosial politik merupakan tuntutan kebutuhan, yang dihadapi bangsa-bangsa dewasa ini. Nampaknya konsep reformasi belum selesai, bahkan dapat dinilai gagal, terutama jika dikaitkan dengan pertanyaan atas fenomena politik dan pemerintahan seperti yang telah dikemukakan.

Islam adalah agama yang sangat menjunjung nilai demokrasi. Nilai-nilai egalitarian, pluralistik, hak dan kewajiban individu, keadilan, kasih sayang, dan nilai musyawarah, serta nilainilai kemanusiaan lainnya yang merupakan substansi ajaran Islam itu sendiri, adalah muatan-muatan nilai demokrasi dalam Islam. ${ }^{1}$

${ }^{1}$ Tobroni dan Syamsul Arifin, Islam Pluralisme Budaya dan Politik, Refleksi 
Perspektif politis, demokrasi memiliki posisi strategis, karena dinilai dapat menjaga iman dan mempertahankan pedoman etik di tengahtengah perubahan yang modern. Islam selalu mengalami kegagalan dalam mengintegrasikan Negara dan agama. Bagi orang mukmin, bahaya sebenarnya penyatuan Islam dan Negara dikarenakan Islam akan berakhir karena tersubordinasikan pada Negara. ${ }^{2}$ Prilaku politik yang bersifat ekspresif, reaksioner terhadap fenomena sosial yang berkembang dengan cara menggunakan kekuatan massa arus bawah, nampaknya sudah "tidakin" lagi pada era demokrasi sekarang ini, apalagi prilaku politik pemerintah yang tiranik (thāgh $\bar{u} t$ ), sebab nilai kemanusiaan merupakan pertimbangan asasi. ${ }^{3}$

Kata egalita ${ }^{4}$ ada yang mensinonimkannya dengan demokratis, sedangkan Nurcholish Madjid menyamakan kata egalitarianisme dengan persamaan, ${ }^{5}$ yang secara substantif memiliki kesamaan dengan demokrasi. Egalitarianisme dapat juga dipahami sebagai doktrin atau pandangan yang menyatakan bahwa manusia itu ditakdirkan sama derajat; atau bisa pula dikatakan sebagai asas pendirian yang menganggap bahwa kelas-kelas sosial yang berbeda

Teologi Untuk Aksi dalam Keberagamaan dan Pendidikan, (Yogyakarta : SI Press, 1994), h.77.

${ }^{2}$ Robert W. Hefner, Civil Islam: Islam dan Demokrasi di Indonesia, Edisi Bahasa Indonesia, (Yogyakarta : Institut Studi Arus Informasi ISAI bekerjasama dengan Asia Foundation, 2001), h. 363.

${ }^{3}$ Visi kemanusiaan ini cukup jelas terlihat dalam al-Qur'an surat al-Ra'd ayat 17 : Allah telah menurunkan air (hujan) dari langit, Maka mengalirlah air di lembahlembah menurut ukurannya, Maka arus itu membawa buih yang mengambang. dan dari apa (logam) yang mereka lebur dalam api untuk membuat perhiasan atau alat-alat, ada (pula) buihnya seperti buih arus itu. Demikianlah Allah membuat perumpamaan (bagi) yang benar dan yang bathil. Adapun buih itu, akan hilang sebagai sesuatu yang tak ada harganya; Adapun yang memberi manfaat kepada manusia, Maka ia tetap di bumi. Demikianlah Allah membuat perumpamaan-perumpamaan [Allah mengumpamakan yang benar dan yang bathil dengan air dan buih atau dengan logam yang mencair dan buihnya. yang benar sama dengan air atau logam murni yang bathil sama dengan buih air atau tahi logam yang akan lenyap dan tidak ada gunanya bagi manusia.].

${ }^{4}$ Kata sifat, yaitu seseorang yang percaya bahwa semua orang sederajat. Lihat, John M. Echols dan Hassan Shadily, Kamus Inggris Indonesia, (Jakarta: PT. Gramedia Pustaka Utama, 1993), h. 208.

${ }^{5}$ Nurcholish Madjid, Islam Doktrin dan Peradaban, (Jakarta: Paramadina dan Dian Rakyat, 2008), h. 72, 102, 254, 463, 466, 445. Persamaan di sini yaitu keadaan equality (esp. sosial and political), lihat, A. S. Hornby et. al, The Advanced Learner's Dictionary of Current English, (London: Oxford University Press), 1973), h. 318. 
mempunyai bermacam-macam anggota, dari yang pandai sampai ke yang sangat bodoh di proporsi yang relatif sama. ${ }^{6}$

Pemikiran modern dalam Islam, seperti paham republik di mana kepala Negara dipilih untuk jangka waktu tertentu, harus tunduk pada Undang-Undang Dasar dan bisa dijatuhkan oleh parlemen;idepersamaan(egalite)dimana rakyatmemilikikedudukan yang sama dalam soal pemerintahan dan ide nasionalisme. Menurut Grunebaum, pertama kali muncul melalui ekspedisi Napoleon Bonaparte ke Mesir.'Dalam konteks sosio-politik, egalitarianisme yang mengandung makna persamaan, menunjukkan arti berlaku moderat dan berimbang pada wilayah politik, ekonomi, sipil dan sosial, yang berlaku dalam hubungan intern antar warga, antar bangsa-bangsa dan Negara; antar etnis dan masyarakat luas.

Muhammad Imarah secara rinci menegaskan tentang konsep persamaan yang realistis adalah persamaan manusia di depan hukum, dengan menghilangkan perbedaan tempat kelahiran, warna kulit, keturunan, etnis dan keyakinan agama. Selanjutnya adalah persamaan dalam memberi kesempatan bagi semua warga, semua bangsa dan Negara dalam kerangka sosial dan Negara sekaligus. ${ }^{8}$ Setelah adanya kesempatan, maka konsep persamaan tidak mungkin diejawantahkan, karena perbedaan penghasilan, pekerjaan, status sosial, agama, warna kulit, etnis dan lain sebagainya sudah merupakan kodrat hukum alam. Imam Ali bin Abu Thalib (600-661 M) mensinyalir bahwa kondisi sosial masyarakat itu bertingkat-tingkat (dalam sosiologi disebut dengan pelapisan masyarakat) yang memiliki ketergantungan satu sama lainnya. ${ }^{9}$ Varma dengan mengutip pendapat Pareto (1848-1923), menegaskan bahwa masyarakat terdiri dari dua kelas; lapisan atas, yaitu pertama : elit, yang terbagi ke dalam elit yang memerintah (governing elite) dan elit yang tidak memerintah (non-governing elite),

${ }^{6}$ Departemen Pendidikan dan Kebudayaan, Kamus Besar Bahasa Indonesia Edisi Kedua, (Jakarta : Balai Pustaka, 1995), h. 250.

${ }^{7}$ G. E. Von Grunebaum, Islam : Essay in The Nature and Growth of a Cultural Tradition, ( London: Routledge and Kegan Paul Ltd, 1969), h. 29.

${ }^{8}$ Muhammad Imarah, Perang Terminologi Islam Versus Barat, (Jakarta: Rabbani Press, 1998), h. 162.

${ }^{9}$ Muhammad Imarah, Perang..., h. 164. 
kedua: lapisan yang lebih rendah, yaitu non-elit. ${ }^{10}$ Seperti kaum buruh, petani, pedagang retil, pengusaha kecil, karyawan dan lain sebagainya.

Perihal egalitarianisme memiliki kesamaan dengan demokrasi, David Beetham mendefinisikan demokrasi sebagai sebuah cara pengambilan keputusan menyangkut aturan dan kebijakan yang mengikat secara kolektif, yang dikenai kontrol oleh rakyat. ${ }^{11}$ Elemen kunci dari definisi ini, yang terkait dengan prinsip egalitarianisme, adalah kontrol masyarakat dan kesetaraan politis. Dari pengertian tersebut, dapat dipahami bahwa demokrasi bisa diterapkan pada setiap kolektivitas, dan tidak membatasi demokrasi pada wilayah politik yang didefinisikan secara sempit. Kolektivitas di sini bisa berupa sebuah Negara, sebuah komunitas lokal, sebuah organisasi, sebuah keluarga, dan sebagainya. ${ }^{12}$ Dengan demikian, demokrasi dapat diterapkan pada semua aspek kehidupan kolektif, Negara, sosial, ekonomi dan lain-lain. Dari sini dapat ditegaskan bahwa politik egalitarianisme adalah membangun komitmen kebersamaan dalam kehidupan politik dengan keharusan mengesampingkan unsur-unsur primordialisme yang menyelimuti manusia.

Membangun politik egalitarianisme secara nalar dapat dipahami sebagai meneladani kepemimpinan politik Nabi yang berpredikat uswatun hasanah, yaitu kepemimpinan moral yang sarat akan nilai-nilai kemanusiaan universal seperti persamaan (equality),

${ }^{10}$ SP. Varma, Teori Politik Modern, (Jakarta: PT. RajaGrafindo Persada, 2001), h. 200.

${ }^{11}$ David Beetham, "Liberal Democracy and the Limits of Democratization", dalam suntingan David Held, Prospects for Democracy North, South. East, West, (Cambridge: Polity Press, 1993), h. 55.

${ }^{12}$ Kolektivitas dalam Islam disebut juga sebagai umat. Bahtiar Effendimenyebutnya sebagai komunitas Islam yang tidak mengenal batas-batas politik atau kedaerahan. Lihat, Bahtiar Effendy, Islam dan Negara Transformasi Pemikiran dan Praktik Politik Islam di Indonesia, (Jakarta: Paramadina, 1998), h.12. dalam konteks sosiologis, Ali Syariati, sebagaimana dikutip oleh Quraish Shihab bahwa ummat didefinisikan sebagai himpunan manusiawi yang seluruh anggotanya bersama-sama menuju satu arah, bahu membahu, dan bergerak secara dinamis di bawah kepemimpinan bersama (kepemimpinan secara kolektif kolegial). Lihat, M. Quraish Shihab, Wawasan Al-Qur'an Tafsir Maudu'i atas Pelbagai Persoalan Umat, (Bandung: Penerbit Mizan, 1997), h. 328-329. 
keadilan (al-'adālah), kemerdekaan (al-hurriyyah), yang semua praktik politiknya merupakan derivasi dari Tauhid, dijadikan acuan dan orientasi secara konsisten Nabi Muhammad dalam kehidupan politik. ${ }^{13}$ Oleh karena itu, dalam konteks membangun politik egalitarian nampaknya memiliki korelasi signifikan dengan nilainilai yang dikembangkan oleh Rasulullah Saw.. dalam memimpin Negara Madinah, yang berpangkal dari ajaran tauhid. Paham tauhid (Ketuhanan Yang Maha Esa) ini memiliki konsekuensi logis pembebasan sosial, yaitu egalitarianisme, sehingga dari prinsip tauhid ini yang dikehendaki adalah sisitem kemasyarakatn yang demokratis berdasarkan musyawarah, transparan dan akuntabel.

Masyarakat egaliter dalam Islam adalah masyarakat yang berfondasikan konsep teologi yang menjadi landasan utama agama Islam, yaitu tauhid, yang menyatakan bahwa Allah itu transenden, unik dan tanpa sekutu. Masyarakat Islam merupakan cerminan dari keesaan Tuhan, tawhìd. Bila "kesatuan" merupakan kenyataan mendasar esensi ketuhanan, maka ia mesti mewujudkan pula dalam konstruksi masyarakat manusia. Masyarakat tawhid tidak bisa mentolerir pengkotakan, baik yang bersifat sosial, etnis, kesukuan, atau nasional maupun wewenang politik yang otonom dalam kaitan dengan tatanan keilahian. Kedaulatan mutlak Tuhan (hakimiyah), dengan demikian, akan tetap berlaku, menguasai segala bentuk kehidupan individu maupun sosial. ${ }^{14}$ Oleh karena itu, kekuasaan politik yang berasas egalitarianisme akan lebih menjamin terwujudnya Negara idaman yang berpredikat baldatun țayyibatun wa rabbun gafūr, yaitu sebuah Negara dengan komunitas yang berkemakmuran dan berkeadilan, seperti halnya Negara Madinah.

\section{B. Keunggulan Negara Madinah dalam Pertimbangan}

Mengaitkan pembicaraan tentang egalitarianisme dengan nilai-nilai yang dibangun dan diimplementasikan Nabi

${ }^{13}$ Tobroni dan Syamsul Arifin, Islam Pluralisme Budaya dan Politik, Refleksi Teologi Untuk Aksi dalam Keberagamaan dan Pendidikan, (Yogyakarta: SI Press, 1994), h. 44.

${ }^{14} \mathrm{Di}$ antara tokoh Sunni, Sayyid Quthb-lah yang mengembangkan konsep hakimiyyah; Lihat, Olivier Roy, Gagalnya Islam Politik, (Jakarta: PT Serambi Ilmu Semesta, 1996), h. 50. 
Muhammad Saw. di Negara Madinah bukan semata-mata melakukan romantisasi terhadap kejayaan Islam awal. ${ }^{15}$ Akan tetapi perlu diingat bahwa sejarah mewujudkan sunnatullah yang umat-Nya diperintahkan untuk mempelajarinya. ${ }^{16}$ Pada saat wahyu diturunkan kepada Nabi, acuan sejarah itu tentunya kepada umatumat sebelum Islam. Maka sekarang acuan itu sudah pasti kepada sejarah Islam sendiri, di mana kaum Muslim harus mengaksesnya, sehingga dapat berperan serta melestarikan apa saja yang baik dan benar dari warisan masa lampau dan bisa dipertahankan dalam ujian ajaran universal Islam. Sejarah Islam yang ideal dan unik yang dapat menjadi dasar pembentukan akidah dan akhlak dalam kerangka pembangunan politik egalitarian adalah Negara Islam Madinah di bawah kepemimpinan Nabi Muhammad Saw., dengan konstitusi Piagam Madinahnya.

Praktik politik pemerintahan di bawah kepemimpinan Rasulullah Saw. di Madinah ${ }^{17}$, dalam Islam memunculkan tiga perspektif yang memiliki perbedaan menonjol dalam wacana pemikiran politik modern. Direvasi praktik politik profetis tersebut memunculkan berbagai perbedaan sudut pandang. Bahtiar Effendy menyederhanakan sebagai pendekatan trikotomi, yaitu

${ }^{15}$ Ada sebagian ulama yang mengkritik bahwa sebutan Negara Madinah itu tidak tepat, sebab ideology politiknya universal. Jika disebut Negara Muhajirin, agaknya kurang tepat, karena tidak ada maksud pendirian Negara tersebut untuk menyingkirkan kaum Anshar. Begitu pula jika disebut sebagai Negara Islam juga kurang tepat, karena dianggap kabur karena merupakan kata sifat. Apa lagi jika dinamakan Negara Hijrah, karena dibentuk setelah hijrah, karena terlalu simplistis. Oleh karena itu Abdul Aziz Thaba mengabaikan perbedaan pendapat tentang penamaan Negara Madinah, baginya, apa pun namanya, merupakan suatu fakta bahwa system yang dibangun oleh Rasulullah Saw. di Madinah itu memenuhi syarat-syarat nominal untuk disebut sebagai Negara. Lihat Abdul Aziz Thaba, Islam dan Negara dalam Politik Orde Baru, (Jakarta: Gema Insani Press, 1996), h. 95-96. Negara sebagai asosiasi memiliki tiga unsur pokok, yaitu pemerintah, komunitas atau rakyat, dan wilayah tertentu (population, territory, a government). Lihat, R.M. Mac. Iver, The Modern State, (London: Oxford University Press, 1947), h. 22. Encyclopaedia Britannica, (London: Encylopaedia Britannica Inc., 1970), vol 21, h. 148.

${ }^{16}$ Q.S al-Ahzāb (33): 62, al-Fāṭir/35:43 dan Ali ‘Imrān/3 : 137 dan lain-lain.

${ }^{17}$ Negara Madinah bisa disebut sebagai sebuah Negara karena telah memenuhi keriteria sebagai Negara, yakni adanya wilayah, rakyat dan pemerintahan. Lihat, Muhammad Salim al-Awwā, Fì al-Nizhām al-Siyāsì $\bar{~} i$ al-Dawlah al-Islāmiyyah, (Kairo: Dār al-Syurūq, 1989), h. 21. 
fundamentalis, reformis, dan akomodasionis. Dengan mengutip pendapat Samson, ia menjelaskan bahwa kaum fundamentalis lebih mengedepankan keutamaan agama atas politik dan menentang habis-habisan pandangan sekular, pengaruh Barat dan sinkritisme kepercayaan tradisional. Sedangkan kelompok reformis, di samping menekankan keutamaan agama atas politik, tetapi mereka bisa bekerja sama dengan kelompok sekular. Kelompok akomodasionis jauh lebih moderat dari kaum reformis, karena mengusung nilainilai demokrasi, toleransi dan humanis. ${ }^{18}$ Para pemikir Islam kontemporer agaknya lebih cenderung kepada paham moderat dan akomodatif, dan tidak cenderung kepada sekularisme ataupun fundamentalisme dalam arti sempit.

Negara Madinah memiliki keunggulan, yang selalu digelorakan oleh para mujahid politik, yaitu Piagam Madinah (Mitsāq al-Madinah) ${ }^{19}$ yang dicetuskan oleh Rasululah Saw. di Madinah bersama kalangan agamawan yang lain, seperti Yahudi dan Nasrani. Piagam Madinah adalah konstitusi sangat modern pada zamannya, sebagaimana dilontarkan Robert N. Bellah. ${ }^{20}$ Dikatakan sangat modern, karena adanya prinsip kemodernan dalam Negara, yang merupakan salah satu bagian terpenting dalam konsep kewarganegaraan, yaitu pluralisme. Dalam Piagam

${ }^{18}$ Bahtiar Effendy, Islam dan Negara Transformasi Pemikiran dan Praktik Politik Islam di Indonesia, (Jakarta : Paramadina, 1998), h. 42. Lihat juga, Allan Samson, "Conceptions of Politics, Power, and Ideology in Contemporary Indonesian Islam", dalam Karl D. Jackson and Lucian W. Pye (eds.), Political Power and Communication in Indonesia, (Berkelay, Los Angeles, London: University of California Press, 1978), h. 199-200.

${ }^{19}$ Pembahasan yang paling representative tentang Piagam Madinah ini, baca lebih lanjut; Ibn Hishām, The Life of Muhammad, a translation of Ishaq's Sirāt al-Rasûl Allah, with introduction and notes by A. Guillaume, (Lahore, Karachi, Dacca: Oxford University Press, 1970), h. 231-233; W. Montgomery Watt, Muhammad at Medina, (Oxford: The Clarendon Press, 1956), h. 221-228. Muhammad Husyn Haykal, The Life of Muhammad, translated by Isma'il Raji al-Faruqi, (North American Publication, 1976), h. 180-183.

${ }^{20}$ Negara kota di bawah kepemimpinan Nabi Muhammad Saw. di Madinah dilihatnya sebagai model nasionalisme yang sangat egalitarian dan partisipatif, sehingga konstitusi Piagam Madinah dinilai sebagai konstitusi yang sangat modern di zamannya. Lihat, Robert N. Bellah, "Islamic Tradition and the Problems of Modernization," dalam kumpulan karangannya, Beyond Belief : Essays on Religion in a Post-Traditionalist World, (Berkeley and Los Angeles: California University Press, 1991). 
Madinah, pluralisme dijunjung tinggi. Perbedaan agama tidak menjadi penghalang pembangunan politik yang menjunjung tinggi kesetaraan, keadilan dan kedamaian. Dengan Piagam Madinah masyarakat egaliter dapat terbangun dengan baik. Menurut Philip K. Hitti, Piagam Madinah atau Konstitusi Madinah itu lebih bersifat politis daripada agamis. ${ }^{21}$ Karena hal-hal yang diatur di dalamnya menyangkut tata kelola masyarakat dan Negara serta pemerintahan.

Masyarakat yang dibangun oleh Nabi Muhammad Saw.. adalah masyarakat yang berbudi luhur, bermoral tinggi dan itulah masyarakat madani yang tertib, dan oleh karena itu wajib ditiru. Masyarakat yang diwariskan Nabi tersebut bercirikan egalitarianisme, penghargaan kepada orang berdasarkan prestasi (bukan prestise seperti keturunan, kesukuan, ras, dan lainlain), keterbukaan partisipasi seluruh anggota masyarakat, dan penentuan kepemimpinan melalui pemilihan secara demokratis, bukan berdasarkan keturunan. ${ }^{22}$ Meskipun prototipe masyarakat yang dibangun Nabi tidak berlangsung lama, hanya samapai masa Khulafā' al-Rāsyidin, dan masa Umar bin Abdul Aziz, tetapi nilai-niali yang telah ditanamkan dapat diterapkan hingga akhir zaman.

Piagam Madinah merupakan ekspresi terbaik dari penerapan nilai-nilai etika politik; seperti keadilan, musyawarah dan egalitarianisme. Ia merupakan rumusan pemerintahan yang mengatur hubungan sosial-politik di kalangan anggota masyarakat Madinah, yang terdiri dari beberapa kelompok keagamaan yang berbeda seperti Muslim, Yahudi dan suku-suku pagan. Oleh karena itulah konstitusi Piagam Madinah dapat menjadi dasar konvergensi sosial-politik di antara sebuah komunitas politik dengan latar belakang yang berbeda, seperti Indonesia. Arti penting Piagam Madinah dalam konteks membangun egalitarianisme politik adalah pada penekanannya pada prinsip keadilan, partisipasi, musyawarah, dan persamaan hak di hadapan hukum. ${ }^{23}$ Konsep-

${ }^{21}$ Philip K. Hitti, Capital Cities of Arab Islam, (Minneapolis: University of Minnesota Press, 1966), h. 34.

${ }^{22}$ Nurcholish Madjid, "Menuju Masyarakat Madani” dalam Tim Maula, Jika Rakyat Berkuasa: Upaya Membangun Masyarakat Madani dalam Kultur Feodal, (Bandung: Pustaka Hidayah, 1999), h. 324.

${ }^{23}$ Bahtiar Effendy, Islam dan Negara Transformasi Pemikiran dan Praktik Politik 
konsep semisal Syūrā (konsultasi), musyāwarah (perundingan), dan musāwa (kesetaraan) tidak hanya cocok dengan demokrasi, tetapi jika diinterpretasikan secara benar, secara implisit dalam konsepkonsep tersebut telah terkandung makna demokrasi. Prinsip-prinsip ini, menurut Anders Uhlin, dapat diterapkan di seluruh wilayah publik, tetapi kebanyakan ilmuan Muslim membatasinya pada apa yang disebut sebagai wilayah politik. ${ }^{24}$

Paradigma Negara modern yang berbasis konsep kontrak sosial dan kontrak politik, jika dilakukan penelaahan yang komprehensif agaknya memperlihatkan koneksitas dengan Piagam Madinah. Praktik-praktik politik dan sosial dalam Islam memperlihatkan hal demikian. Kontrak Nabi Muhammad dengan penduduk Madinah dalam "Bait Aqabah" sesungguhnya merupakan salah satu model kontrak politik. Sedangkan persaudaraan antara kaum Muhajirin dan Anshar merupakan salah satu bentuk kontrak sosial. Praktik politik yang berdimensi teologis dan humanistis ini menegaskan bahwa Nabi Muhammad Saw. membawa reformasi sosial yang monumental. Al-Qur'an sendiri mengaitkan keimanan serta penerimaan seruan Nabi dengan usaha reformasi dunia (iṣlāh al-ard), nampaknya diakui, baik oleh kalangan Muslim maupun nonMuslim, telah dilaksanakannya dengan sukses luar biasa. ${ }^{25}$

Ekspresi persatuan dan kesatuan serta kedamaian antar umat beragama diikat dalam konstitusi Madinah. Di samping membina intern umat Islam, Nabi Muhammad Saw., menjalin hubungan yang harmonis dengan masyarakat non-Muslim, yang ditetapkan ketentuan-ketentuan yang sangat toleran, yang jauh berbeda dari kebiasaan yang berlaku sebelumnya dengan fanatisme kesukuan dan ras. Sehingga yang disatupadukan oleh Nabi adalah golongan Muslim Muhajirin (Mekah) dan golongan Muslim Anshar (Madinah) dengan kelompok-kelompok, suku-suku, atau kabilah-kabilah musyrikin yang paganis, juga kaum Yahudi dan Nasrani, sehingga

Islam di Indonesia, (Jakarta: Paramadina, 1998), h. 185-187.

${ }^{24}$ Anders Uhlin, Oposisi Berserak Arus Deras Demokratisasi Gelombang Ketiga di Indonesia, terj. Rofik Suhud, (Bandung: Mizan, 1998), h. 73.

${ }^{25}$ Gambaran tentang kesuksesan Nabi Muhammad Saw. melakukan reformasi dengan luar biasa, dapat dilihat pada Michael H. Hart, The 100, a Ranking of the Most Influential Persons in History, terj. Mahbub Djunaidi, "Teratus Tokoh yang Paling Berpengaruh dalam Sejarah”, (Jakarta: Pustaka Jaya, 1986), h. 27. 
terbentuklah sebuah komunitas baru yang lebih kompleks dengan elemen-elemen yang heterogen, dengan struktur masyarakat yang sekarang dikenal sebagai Negara. ${ }^{26}$

Paparan wacana di atas agaknya meniscayakan bahwa menyikapi keterkaitan masyarakat madani dengan demokrasi, paling tidak, sebagai kontribusi masyarakat madani terhadap proses demokrasi adanya penyediaan wahana sumberdaya politik, ekonomi, kebudayaan dan moral untuk mengawasi dan menjaga keseimbangan pejabat Negara. ${ }^{27} \mathrm{Hal}$ ini dapat dipertegas dengan konstruksi masyarakat madani yang tercipta bermula dari kesederhanaan seorang pemimpin negara sebagai sikap hidup yang menjadi pilar utama uswah hasanah terhadap seluruh rakyat yang dipimpinnya.

\section{Refleksi Pemikiran Politik Egalitarian}

Sejarah Nabi dan para sahabat, di samping al-Qur'an dan sunnah, merupakan parameter dan inspirasi rumusan pemikiran politik Islam, oleh karena itu, gagasan egalitarianisme politik tidak terlepas dari substansi pemikiran tersebut ${ }^{28}$ Jika konsep masyarakat egalitarian sinonim dengan masyarakat demokratis, maka administrasi pemerintahan berada di tangan banyak pihak, sehingga musyawarah dan kehidupan pluralistik menjadi keniscayaan, dengan pola ini pemerintahan Athena dikonotasikan sebagai "pemerintahan tanpa pemerintah", karena rakyat adalah pemerintah. ${ }^{29}$ Mengambil ibrah dari ilustrasi bahwa Negara kota Yunani sebagai kota pendidikan (madrasatun kubra) untuk semua warga Yunani, di mana setiap individu mereka merupakan contoh

${ }^{26}$ Marshall G.S. Hodgson, The Ventur of Islam, (Chicago, London:The University of Chicago University Press, 1974), Vol I, h. 193.

27Abdul Razak et al (ed.,), Pendidikan Kewargaan (Civil Education); Demokrasi, Hak Asasi Manusia dan Masyarakat Madani, (Jakarta: ICCE UIN Syarif Hidayatullah dan The Asia Foundation serta Prenada Media, 2003), h. 253.

28Bahtiar Effendi dalam "Disartikulasi Pemikiran Politik Islam ?", dalam Pengantar buku Olivier Roy, Gagalnya Islam Politik, terj. (Jakarta: PT Serambi Ilmu Semesta, 1996), h. vii.

29Kesimpulan dramator Aeschylus, lihat Henry J. Schmandt, Filsafat Politik Kajian Historis dari Zaman Yunani Kuno Sampai Zaman Modern, (Yogyakarta: Pustaka Pelajar, 2005), h. 37. 
dari kemerdekaan berpikir. ${ }^{30}$ Maka negara kota Madinah yang dibangun oleh Nabi, merupakan prototipe kota pendidikan politik bagi semua orang yang mengaku Muslim, karena dengan jelasjelas bahwa diutusnya beliau sebagai suri tauladan bagi umatnya, termasuk meneladani praktik politik egalitarian yang telah didirikannya.

Salah satu ekspresi Islam berwatak moderat adalah konsep egalitarianisme dalam Islam yang mengejawantah dalam konsep sikap berada di tengah-tengah (at-tawassuț), sikap adil (al-i'tidal), dan seimbang (at-tawäzun). Ketiga konsep moderasi Islam dalam bersikap dalam kehidupan sosial dan politik ini didukung oleh ayat-ayat alQur'an sebagaimana dalam Q.S. al-Baqarah (2): 143 dinyatakan:

Dan demikian (pula) Kami telah menjadikan kamu (umat Islam), umat yang adil dan pilihan [Umat Islam dijadikan umat yang adil dan pilihan, karena mereka akan menjadi saksi atas perbuatan orang yang menyimpang dari kebenaran baik di dunia maupun di akhirat].

M. Quraish Shihab mensinyalir bahwa wasat adalah posisi di antara dua ekstrem. Keberanian adalah posisi pertengahan antara ceroboh dan takut, kedermawanan merupakan pertengahan antara sikap boros dan kikir, kesucian merupakan pertengahan antara nafsu libido seksual dengan impotensi. Dari kata wasat menjadi penengah di anatar dua pihak yang sedang berseteru disebut wasit, dan berada pada posisi tengah agar berlaku adil, sehingga lahirlah makna ketiga dari wasat yaitu adil. Lebih lanjut, Shihab menegaskan bahwa ummatan wasatha adalah umat moderat, yang posisinya di tengah. Posisi tengah menjadikan perpaduan berimbang antara aspek ruhani dan jasmani, material dan spiritual dalam segala sikap dan aktivitas. ${ }^{31}$

Sikap moderat yang paling patut diteladani dari sikap Rasulullah adalah toleransi (tasāmuh) terhadap perbedaan pendapat baik dalam masalah keagamaan maupun dalam masalah kemasyarakatan dan kebudayaan, bahkan dalam masalah politik. Dengan kata lain dapat ditegaskan bahwa Islam tidak membenarkan

${ }^{30}$ Henry J. Schmandt, Filsafat Politik Kajian Historis dari Zaman Yunani Kuno Sampai Zaman Modern, (Yogyakarta: Pustaka Pelajar, 2005), h. 31.

${ }^{31}$ M. Șihab, Wawasan Al-Qur'an....., (Bandung: Penerbit Mizan, 1997), h. 328329. 
sikap ekstrem/ menghujung (tațarruf), yaitu melihat sesuatu hanya dari satu ujung saja dan sikap berlebih-lebihan, yang pada akhirnya memunculkan aliran-aliran sempalan yang memiliki konotasi politis yang "merugikan" Islam itu sendiri. ${ }^{32}$ Moderasi atau posisi tengah mengundang umat Islam untuk berinteraksi, berdialog, dan terbuka dengan semua pihak (agama, budaya, dan peradaban). Sikap dan jalan hidup inilah yang ditegaskan al-Qur'an bahwa komunitas Muslim itu sebagai khaira ummah. ${ }^{33}$

Sikap politik yang ahistoris adalah politik violent, seperti dikemukakan oleh al-Farrā' yang mengatakan bahwa khilafah Islam adalah benteng pertahanan, yang akan memerangi siapa saja yang enggan masuk Islam setelah mendapat dakwah Islam sampai kepadanya. ${ }^{34}$ Kemudian Imam Ibnu Taimiyah mengatakan bahwa khilafah Islam tetap diperlukan oleh ummat, meski korup sekalipun, sebab dengan adanya institusi tersebut, jihad bisa ditegakkan sampai kapan pun. ${ }^{35}$ Pendapat Ibn Taimiyyah tersebut jika ditarik sudut spektrum hadis yang mengatakan :

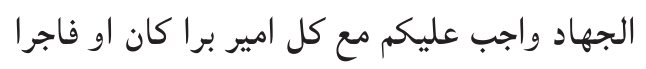

"Jihad ini wajib atas kalian, bersama dengan setiap pemimpin, baik

${ }^{32}$ Zuhairi Misrawi mensinyalir bahwa sikap toleran yang berwawasan pluralistis ditandaskan pada dokumen politik Piagam Madinah, lihat Zuhairi Misrawi "Fikih Civil Society Versus Fikih Kekuasaan : Sebuah Tawaran Pembaruan Politik Islam”, dalam Komaruddin Hidayat dan Ahmad Gaus AF (ed.), Islam Negara Civil Society Gerakan dan Pemikiran Islam Kontemporer, (Jakarta: Paramadina, 2005), h. 286.

${ }^{33}$ Pada Q.S Ali Imran ayat 110 disebutkan bahwa :"Kamu adalah umat yang terbaik yang dilahirkan untuk manusia, menyuruh kepada yang ma'ruf, dan mencegah dari yang munkar, dan beriman kepada Allah. Sekiranya ahli kitab beriman, tentulah itu lebih baik bagi mereka, di antara mereka ada yang beriman, dan kebanyakan mereka adalah orang-orang yang fasik".

${ }^{34} \mathrm{Abū}$ Ya'la Muhammad bin al-Hussein al-Farrā', al-Ahkām as-Sulțāniyah, (Beirut: Dār al-Kutub al-Ilmiyah, 1983), h. 27.

${ }^{35}$ Syaikh al-Islām Taqiyuddin Abū Abbas Ahmad bin Abdu al-Halim bin Abdussalām bin Taimiyyah, as-Siyāsah as-Syar'iyyah, (Beirut: Dār al-Fikr al-Lubnani, 1992), h. 55.

Syaikh al-Islām Taqiyuddin Abū Abbas Ahmad bin Abdu al-Halim bin Abdussalām bin Taimiyyah, as-Siyāsah as-Syar'iyyah, (Beirut: Dār al-Fikr al-Lubnani, 1992), h. 55. 
yang ta'at maupun yang korup". (H.R. Abū Dāwūd dan Abū Ya'la dari Abū Hurairah) $)^{36}$

Sejauh ini, terdapat tiga teori mengenai dasar-dasar pembentukan khilafah. Pertama, Abu Hasan al-Asy'ari mengatakan bahwa pembentukan khilafah wajib hukumnya berdasarkan syari'ah, baik wahyu maupun ijma' sahabat. Kedua, Mawardi mengatakan hukumnya fardu kifayah berdasarkan ijma' atau konsensus, dan ketiga, kaum Mu'tazilah mengatakan wajib tetapi berdasarkan pertimbangan akal. ${ }^{37}$ Gagasan mengenai kepemimpinan ummat (khilafah Islamiyyah), terlepas dari hukumnya wajib, atau fardlu kifayah, atau usaha pelegalformalan syari'at dalam Negara, patut diapresiasi setinggi-tingginya, alias acungan dua jempol.

Perjuangan politik yang bertujuan mendirikan khilāfah Islāmiyyah adalah perjuangan politik yang patut dihargai, tetapi perjuangan tersebut menjadi tidak realistis dan juga tidak berlandaskan pada kenyataan objektif situasi politik, padahal suatu perjuangan tidak hanya sekedar semangat, tetapi juga dibutuhkan taktik dan strategi yang tepat untuk konteks dan waktu yang tepat, sesuai dengan zamannya. Oleh karena itu, yang lebih faktual, objektif, realistis dan baik untuk konteks Islam saat ini adalah mewujudkan masyarakat yang berdimensi ketuhanan, seperti yang digagas oleh Al-Farabi, yang ia paparkan sebagai Negara kota yang beradab, yaitu sebuah masyarakat atau Negara yang mewujudkan segala keutamaan di atas dasar Ketuhanan Yang Maha Esa. ${ }^{38}$

Terlepas dari kualitas hadis itu șahih atau tidak, secara substantif bersifat indoktrinasi yang bertentangan dengan prinsipprinsip kemanusiaan dan ajaran Islam. Bagaimana mungkin

${ }^{36}$ Al-Imām al-Ḥāfidz Abdurrahmān Jalāluddinn As-Suyuṭi, al-Jāmi' As-Ṣagìr fi Ahadis Al-Basyār an-Nazir, (Beirut: Dār al-Fikr, tt. Juz I), h. 564, hadis nomor 3653.

${ }^{37}$ M. Dawam Rahardjo, Ensiklopedia al-Qur'an : Tafsir Sosial Berdasarkan Konsepkonsep Kunci, (Jakarta: Paramadina, 1996), h. 362. Abū Hasan Ali bin Muhammad bin Habīb al-Bașri Al-Mawardi, Al-Ahkām al-Sulțāniyyah fi al-Wilāyāt ad-Dīniyyah, (Beirut: Dār al-Kitāb al-'Arabỉ, t.t), h. 5. Abū Ya'la Muhammad bin al-Hussein Al-Farrā', alAhkām as-Sulțāniyah, (Beirut: Dār al-Kutub al-Ilmiyah, 1994), h. 23

${ }^{38}$ Muhsin Mahdi, “al-Farabi”, dalam Leo Stratuss Joseph Grospey (ed.), History of Political Philosophy, (Chicago: 1963), seperti yang dikutip oleh Syarifuddin Jurdi, Pemikiran Politik Islam Indonesia Pertautan Negara, Khilafah, Masyarakat Madani dan Demokrasi, (Yogyakarta: Pustaka Pelajar, 2008), h.516- 518 
pada satu sisi Islam mengajarkan perilaku politik yang etis dan menentang apa pun bentuk korupsi dan kekerasan, namun di sisi lain di suruh menaati pemimpin yang korup dan otoriter. Ajaran ini mengandung kekerasan politik yang luar biasa. Seorang Rajiv Gandhi saja, yang non-Muslim, dengan tegas mengatakan : "Tak ada yang lebih tercela selain kekerasan atas nama agama. Kekerasan atas nama agama berarti menegasikan agama”. ${ }^{39}$ Artinya, apalagi Islam jelas-jelas menentang apa pun bentuk kekerasan. Oleh karena itu hadis di atas hanya dilihat oleh Ibn Taimiyyah dalam perspektif politik. Tidak dalam perspektif agama, karena justru pandangan tersebut dapat menegasikan agama.

Pandangan yang keras dan bersifat kekerasan, sebagimana telah diilustrasikan di atas, diberi istilah oleh kaum orientalis sebagai pandangan kelompok fundamentalis, yang pada akhirnya menciptakan konflik-konflik yang mengganggu hubungan antar manusia. Selanjutnya, metode-metode yang dipakai gerakan fundamentalis yang eksklusif, indoktrinasi, fanatisme, pada hakekatnya tidak memanusiakan manusia, sebab tidak membantu menciptakan keserasian hubungan antar manusia dalam masyarakat dan dunia yang semakin pluralistis. ${ }^{40}$ Jika dihubungkan dengan praktik politik Nabi dalam Negara Madinah, jelas bahwa pandangan kaum fundamentalis adalah ahistoris dan bertentangan dengan nilai-nilai egalitarianisme yang dikembangkan Islam, sekaligus menegasikan keunikan Islam sebagai satu-satunya penjamin keselamatan, baik di muka bumi sekarang maupun keselamatan di akhirat kelak. Dengan demikian Islam menempati posisi starategis membangun egalitarianisme spiritual, dalam konteks pembangunan perdamaian dunia. ${ }^{41}$

\section{Membangun Prinsip Egalitarianisme}

Usaha yang dapat dilakukan dalam karakter building adalah

${ }^{39}$ D.H.W. Gensichen, "Perang dan Damai dalam Agama”, dalam Ali Noer Zaman, (ed.), Agama untuk Manusia, (Yogyakarta : Pustaka Pelajar, 2000), h. 145.

${ }^{40}$ Kamaruzzaman, Relasi Islam dan Negara Perspektif Modernis dan Fundamentalis, (Magelang: Indonesia Tera, 2001), h. 21.

${ }^{41}$ Abdul Aziz Sachedina "Theologi Islam Mengenai Hubungan MuslimKristen, dalam Ali Noer Zaman, (ed.), Agama untuk Manusia, (Yogyakarta : Pustaka Pelajar, 2000), h. 145. 
membangun dan meningkatkan kualitas kepribadian Islam, yaitu dengan cara meminimalisir kemungkinannya untuk melakukan maksiat dan meningkatkan ketaatannya kepada Allah Swt. Dalam hal ini posisi manusia berada di tengah-tengah, yaitu ia sebagai makhluk bukan setan dan bukan pula malaikat. Maka dari itu sifat manusia adalah membangun prinsip check and balance, prinsip keseimbangan. Dalam konteks politik, prinsip egalitarianisme menopang penguatan masyarakat sipil dalam Negara untuk lebih berperan, yaitu suatu masyarakat sipil yang sehat mensyaratkan Negara yang beradab (civilized). Dengan demikian, Negara akan bekerja dengan kebesaran warganya dan humanistisisme Islam sipil. ${ }^{42}$

Hai orang-orang yang beriman, peliharalah dirimu dan keluargamu dari api neraka yang bahan bakarnya adalah manusia dan batu; penjaganya malaikat-malaikat yang kasar, keras, dan tidak mendurhakai Allah terhadap apa yang diperintahkan-Nya kepada mereka dan selalu mengerjakan apa yang diperintahkan. (Q.S. atTahrim : 6).

Selanjutnya disebutkan pula pada ayat lain:

Maka Allah mengilhamkan kepada jiwa itu (jalan) kefasikan dan ketakwaannya. (Q.S. as-Syams : 8).

Prinsip egaliter di antaranya adalah tidak emosional dalam merespon perbedaan pendapat. Menghargai orang yang berbeda pandangan, bersikap lemah lembut ketika berdiskusi dengan orang lain, namun tidak mengurangi sikap tegas dan berani meluruskan kesalahan orang atau pemimpin yang zhalim, sebagaimana ditegaskan dalam al-Qur'an berikut ini:

Maka disebabkan rahmat dari Allah-lah kamu Berlaku lemah lembut terhadap mereka. Sekiranya kamu bersikap keras lagi berhati kasar, tentulah mereka menjauhkan diri dari sekelilingmu. karena itu ma'afkanlah mereka, mohonkanlah ampun bagi mereka, dan bermusyawaratlah dengan mereka dalam urusan itu[Maksudnya: urusan peperangan dan hal-hal duniawiyah lainnya, seperti urusan politik, ekonomi, kemasyarakatan dan lain-lainnya.]. kemudian apabila kamu telah membulatkan tekad, Maka bertawakkallah kepada Allah.

${ }^{42}$ Robert W. Hefner, Civil Islam : Islam dan Demokrasi di Indonesia, Edisi Bahasa Indonesia, (Yogyakarta : Institut Studi Arus Informasi ISAI bekerjasama dengan Asia Foundation, 2001), h. 46. 
Sesungguhnya Allah menyukai orang-orang yang bertawakkal kepadaNya. (Q.S. Ali 'Imrān : 159).

Membangun masyarakat egaliter menjadi agenda transformasi sosial kaum aktivis reformis, yang sangat dipengaruhi dan dibentuk oleh etos emansipasi sosial. Perjuangan mengusung pembelaan terhadap kaum tertindas (mustadl'afin), egalitarianisme, keadilan sosial, demokratisasi ekonomi dan politik. ${ }^{43}$ Oleh karena itu, Islam sangat concern dengan prinsip kemanusiaan. Islam mengajarkan bahwa masing-masing jiwa manusia mempunyai harakat dan martabat yang senilai dengan manusia sejagad. Masingmasing pribadi manusia memiliki nilai kemanusiaan universal. Dokumen pendukung pandangan ini adalah penegasan al-Qur'an bahwa kejahatan kepada seorang pribadi adalah sama dengan kejahatan kepada manusia sejagad, dan kebaikan kepada seorang pribadi adalah sama dengan kebaikan kepada manusia sejagad. ${ }^{44}$ Inilah dasar yang amat tegas dan tandas bagi pandangan kewajiban manusia untuk menghormati sesamanya dengan hak-hak asasinya yang sah.

Konstruksi pembangunan politik yang berkarakter egalitarian adalah rekruitmen pemimpin politik, pemerintahan, penyelenggara Negara dan lain sebagainya secara proporsional, profesional, dan berkeadilan. Kepemimpinan yang distruktif, justru

${ }^{43}$ Bahtiar Effendy, Islam dan Negara Transformasi Pemikiran dan Praktik Politik Islam di Indonesia, (Jakarta: Paramadina, 1998), h. 172-173.

${ }^{44}$ Q.S. al-Maidah/5 : 32. yang mengatakan: "Oleh karena itu Kami tetapkan (suatu hukum) bagi Bani Israil, bahwa: Barangsiapa yang membunuh seorang manusia, bukan karena orang itu (membunuh) orang lain [Yakni: membunuh orang bukan karena qishaash], atau bukan karena membuat kerusakan dimuka bumi, Maka seakan-akan Dia telah membunuh manusia seluruhnya[Hukum ini bukanlah mengenai Bani Israil saja, tetapi juga mengenai manusia seluruhnya. Allah memandang bahwa membunuh seseorang itu adalah sebagai membunuh manusia seluruhnya, karena orang seorang itu adalah anggota masyarakat dan karena membunuh seseorang berarti juga membunuh keturunannya]. dan Barangsiapa yang memelihara kehidupan seorang manusia, Maka seolah-olah Dia telah memelihara kehidupan manusia semuanya. dan Sesungguhnya telah datang kepada mereka Rasul-rasul Kami dengan (membawa) keterangan-keterangan yang jelas, kemudian banyak diantara mereka sesudah itu[Ialah: sesudah kedatangan Rasul membawa keterangan yang nyata] sungguh-sungguh melampaui batas dalam berbuat kerusakan dimuka bumi". Ulasan mengenai hal Islam sebagai agama kemanusiaan, lihat Nurcholish Madjid, Cendikiawan dan Religiusitas Masyarakat, (Jakarta: Tabloid Tekad dan Paramadina, 1999), h. 148. 
menghancurkan kepercayaan rakyat dan sekaligus menghancurkan Negara yaitu, salah satu indikatornya, kepemimpinan yang hepokrit, yaitu tidak adanya kesatupaduan antara perkataan dan perbuatan. Sumpah dan janji ketika kampanye tidak menjadi kenyataan setelah ia berkuasa. ${ }^{45}$ Maka dari itu, salah satu faktor utama keberhasilan pemerintahan Negara Madinah adalah konsep keteladanan yang dipraktikkan Nabi Muhammad Saw., menjadi keniscayaan yang harus dilaksanakan oleh para pemimpin. Paling tidak, keriteria pemimpin yang bermartabat adalah; 1). jujur (shidiq/ adanya watak kenegarawanan, mementingkan bangsa dan Negara ), 2), amanah (kepemimpinan yang akuntebel, kredibel dan akseptibel), kekuasaan meruapak suatu amanah yang harus dijalankan dengan baik sesuai dengan perintah Allah, oleh sebab itu apa pun bentuk penyimpangan dan penyalahgunaan kekuasaan tidak dapat ditolerir, 3), fathanah (adanya respek dan keperihatinan terhadap situasi dan kondisi rakyat, cerdas mencari solusi terhadap permasalahan), dan 4), tabligh (adanya komunikasi politik yang baik antara pemerintah denga sesama pemerintah, penyelenggara Negara dan dengan rakyat).

Prinsip egalitarianiseme dapat berdiri kokoh jika dibangun di atas pondasi keadilan. Pentingnya penegakan keadilan ini menjadi aikon perjuangan para aktivis, karena keadilan merupakan sesuatu yang harus senantiasa diperjuangkan dan ditegakkan dalam masyarakat. Keadilan merupakan prinsip keseimbangan dalam kehidupan manusia. Prinsip ini berkaitan erat dengan prinsip persamaan (egalitarian) antara sesama manusia. Islam tidak membeda-bedakan manusia berdasarkan warna kulit, suku bangsa, bahasa dan ras, tetapi berdasarkan ketakwaannya kepada Allah. ${ }^{46}$ Karena itu, tidak ada seorang pun yang berhak memperoleh perlakuan khusus di depan hukum. Sikap pemerintah yang diskriminatif dalam menegakkan hukum, di mana rakyat jelata diberi hukuman yang seberat-beratnya, lalu membiarkan para konglomerat dan elit penguasa yang melakukan pelanggaran hukum. Hal ini merupakan awal dari kehancuran suatu bangsa. ${ }^{47}$

${ }^{45} \mathrm{Q}$. S. al-Shaf/ 61 ayat 3 yang menandasakan bahwa: "Amat besar kebencian di sisi Allah bahwa kamu mengatakan apa-apa yang tidak kamu kerjakan”.

${ }^{46}$ Q.S. al-Hujurāt/49:13.

${ }^{47}$ Sekedar member contoh, rakyat jelata yang mencuri $2 \mathrm{~kg}$ kapuk atau 3 
Negara ideal yang dituju oleh politik Islam tetap mempertahankan eksistensi agama dalam Negara secara menyatu (integrated) atau minimal terdapat titik temu (intersection) antara agama dan Negara, bukan hubungan yang terpisah antara keduanya (secularistic). Masykuri Abdillah mensinyalir, bahwa integrasi agama dengan Negara berbentuk integrasi dalam sistem, di mana ajaranajaran Islam menjadi aturan hukum atau sistem Negara, dan integrasi dalam bentuk kelembagaan atau figur, di mana pimpinan agama adalah juga pemimpin Negara. Kedua bentuk ini terjadi pada masa Nabi dan Khulafā' al-Rasyidin. Menurut Masykuri, yang lebih pas dalam konteks Indonesia adalah integrasi agama dan Negara dalam bentuk sistem..$^{48}$ Namun demikian, konsep kerukunan hidup beragama yang meliputi : kerukunan intern umat beragama, kerukunan antar umat beragama dan kerukunan antar umat beragama dan pemerintah, dalam konteks politik dan persamaan hak tetap menjadi skala prioritas yang harus dijaga.

\section{E. Prinsip-Prinsip Egalitarianisme Islam}

Islam menjunjung tinggi secara konsisten dan konsekuen prinsip persamaan antara sesama manusia. Unsur pembeda antara manusia yang satu dengan yang lainnya hanya satu yaitu ketakwaan kepada Allah Swt. Dengan demikian, persamaan di sini berdimensi teologis, yang takwa (mentaati segala perintah Allah Swt dan menjauhi segala larangan-Nya) itu lah yang dapat dijadikan pemimpin. Hal inilah yang telah menginspirasi para elit politik Indonesia yang merumuskan Undang-Undang Dasar 1945 dan Pancasila berdimensi teologis. Yaitu "dengan Rahmat Tuhan Yang Maha Esa” dalam UUD-1945, dan "Ketuhanan Yang Maha Esa” dalam Pancasila.

biji kakau dihukum 6 bulan penjara, karena terkena pasal pencurian. Sedangkan pembobol BLBI(Bantuan Likuiditas Bank Indonesia) dan kasus Century, mereka bebas berkeliaran, bahkan kasusnya cenderung “dipeti-es-kan”, sehingga akuntabilitas penguasa dipertanyakan.

${ }^{48}$ Masykuri Abdillah, “ Negara Ideal Menurut Islam dan Implementasinya Pada Masa Kini” dalam Komaruddin Hidayat dan Ahmad Gaus AF, Islam Negara dan Civil Society Gerakan dan Pemikiran Islam Kontemporer, (Jakarta: Paramadina, 2005), h. 82 . 
Prinsip persaudaraan dan persatuan ${ }^{49}$ serta perdamaian merupakan prinsip-prinsip umum yang dapat memperkuat wawasan egalitarianisme. Dengan prinsip-prinsip ini maka dapat dikembangkan pada prinsip profesionalisme dan akuntabilitas publik dalam pengisian jabatan pemerintahan. Penegakan hak asasi manusia merupakan hal yang sangat diperhatikan, oleh karena itu, apa pun bentuknya, pelanggaran HAM tidak dibenarkan dalam Islam. Dalam perspektif egalitarian, penegakan HAM ditujukan kepada semua orang.

Penegakan HAM yang tanpa pilih bulu, merupakan ekspresi dari prinsip persamaan dan keadilan. Sebagai dimensi kunci, prinsip keadilan ditujukan untuk membangun masyarakat yang sejahtera. Oleh karena itu, prinsip keadilan sosial menemukan signifikansinya dalam kehidupan sosial. Fazlurrahman mensinyalir bahwa prinsip egalitarianisme Islam bermuara kepada perintah-perintah keadilan sosial dalam sektor sosial. ${ }^{50}$ Salah satu prinsip keadilan sosial dan ekonomi yang diletakkan al-Qur'an adalah:

Supaya harta itu jangan beredar di antara orang-orang Kaya saja di antara kamu. (Q.S al-Hasyr : 7).

Dari ayat ini jelas kiranya bahwa kekayaan tidak boleh beredar hanya di kalangan orang kaya. Sebagai pengejawantahan prinsip ini, al-Qur'an menetapkan zakat:

Sesungguhnya zakat-zakat itu, hanyalah untuk orang-orang fakir, orang-orang miskin, pengurus-pengurus zakat, Para mu'allaf yang dibujuk hatinya, untuk (memerdekakan) budak, orang-orang yang berhutang, untuk jalan Allah dan untuk mereka yuang sedang dalam perjalanan, sebagai suatu ketetapan yang diwajibkan Allah, dan Allah Maha mengetahui lagi Maha Bijaksana. (Q.S. at-Taubah : 60).

Paparan ayat tersebut cukup jelas menegaskan bahwa yang berhak menerima zakat ialah: 1). orang fakir: orang yang amat sengsara hidupnya, tidak mempunyai harta dan tenaga

${ }^{49}$ Prinsip Islam tentang persatuan ini ditegaskan dalam al-Qur'an beberapa kali sebagai ummatan wahidah; lihat pada al-Baqarah ayat 213; al-Maidah ayat 48; Yunus ayat 19; Hud ayat 18; An-Nahl ayat 93; al-anbiya' ayat 92; al-Mukminun ayat 52; Az-Zukhruf ayat 23; Lihat, Muhammad Fuad Abdul Baqy, Al-Mu'jam al-Mufahras Lialfazh al-Qur'an al-Karim, (Indonesia: An-Nasyir Maktabah Dahlan, t.t), h. 102.

${ }^{50}$ Fazlurrahman, “interpreting the Qur'an” Inquiry, Mei 1986, h. 49. 
untuk memenuhi penghidupannya. 2). orang miskin: orang yang tidak cukup penghidupannya dan dalam keadaan kekurangan. 3). pengurus zakat: orang yang diberi tugas untuk mengumpulkan dan membagikan zakat. 4). muallaf: orang kafir yang ada harapan masuk Islam dan orang yang baru masuk Islam yang imannya masih lemah. 5). memerdekakan budak: mencakup juga untuk melepaskan Muslim yang ditawan oleh orang-orang kafir. 6). orang berhutang: orang yang berhutang karena untuk kepentingan yang bukan maksiat dan tidak sanggup membayarnya. Adapun orang yang berhutang untuk memelihara persatuan umat Islam dibayar hutangnya itu dengan zakat, walaupun ia mampu membayarnya. 7). pada jalan Allah (sabilillāh): yaitu untuk keperluan pertahanan Islam dan kaum muslimin. di antara mufassirin ada yang berpendapat bahwa fi sabilillāh itu mencakup juga kepentingan-kepentingan umum seperti mendirikan sekolah, rumah sakit dan lain-lain. 8). orang yang sedang dalam perjalanan yang bukan maksiat mengalami kesengsaraan dalam perjalanannya.

Wawasan egalitarianisme tentang badan-badan sosial dan politik, al-Qur'an meletakkan prinsip bahwa kaum muslimin harus memutuskan masalah-masalah mereka berdasarkan syūrā ${ }^{51}$ Prinsip syūrā ini berlaku untuk semua bidang; politik, religious, sosial, ekonomi, dan sebagainya. ${ }^{52}$ al-Qur'an mendasari prinsip egalitarianisme ini dengan ayat:

Dan (bagi) orang-orang yang menerima (mematuhi) seruan Tuhannya dan mendirikan shalat, sedang urusan mereka (diputuskan) dengan musyawarat antara mereka; dan mereka menafkahkan sebagian dari rezki yang Kami berikan kepada mereka. (Q.S. as-Syu.arā' : 38).

${ }^{51}$ Selain dalam Q.S 42 : 38 di atas, tentang syūrā ini terdapat juga pada surat al-Baqarah ayat 233, yang membicarakan tentang kesepakatan (musyawarah) yang harus ditempuh suami istri kalau mereka ingin menyapih anak sebelum dua tahun. Juga pada surat Āli Imrān ayat 159, yang berlaku lebih umum dalam konteks yang lebih luas. Di mana seorang pemimpin harus bermusyawarah dengan para bawahannya sebelum mengambil keputusan, seperti konteks ayat ini dalam peristiwa Perang Uhud yang membawa kekalahan umat Islam, karena mengambil keputusan tanpa musyawarah.

${ }^{52}$ Fazlurrahman, Major Themes of the Qur'an, (Minneapolis. Chicago: Bibliotheca Islamica, 1980). Khususnya dalam BAB II, dikupas secara luas bagaimana visi al-Qur'an tentang keadilan sosio-ekonomik dan egalitarianism. 
Prinsip egalitarianisme dalam Islam, pada ayat di atas, memperlihatkan konsistensi landasan teologis yang menjiwai aktivitas sosial dalam bentuk kepedulian sosial. Ayat ini merefleksikan iman, Islām, ihsān dan taqwā seorang muslim, yang menjadi etika al-Qur'an. Refleksi dan internalisasi terhadap ayat ini secara langsung akan mengarahkan ke dalam "bawah sadar" makna paling hakiki yang terdalam atau elan-dasarnya, yang ditujukan untuk melindungi dan mengembangkan integritas individu serta kolektif.

Di dalam al-Qur'an terdapat prinsip-prinsip atau nilainilai yang dijadikan oleh Rasulullah Saw. dalam praktik politik kepemimpinannya di Madinah, yang ternyata di abad modern ini diapresisai oleh Negara-negara beradab pada umumnya, ${ }^{53}$ walaupun tidak persis sama dengan konsep Islam, sebagaimana dipaparkan oleh Masykuri Abdillah di antaranya adalah al-Amānah (Kejujuran dan tanggung jawab), ad-'Adālah (Keadilan), al-Ukhuwah (Persaudaraan), At- Ta'aduddiyyah (Menghargai kemajemukan atau pluralisme), al-Musāwah (Persamaan), asy-Syūrā (Permusyawaratan), al-Silm (Perdamaian), Amr bi al-Ma'rūf nahy 'an al- Munkar (Kontrol). ${ }^{54}$

Mengintegrasikan nilai-nilai Islam tersebut ke dalam ranah politik merupakan penegakan etika. Meski etika dan politik merupakan dua entitas yang berbeda, tetapi salaing membutuhkan. Dalam paradigm ini politik dapat diwarnai oleh nilai-nilai agama, terutama nilai-nilai moral, pada sisi lain, etika dan moral agama dapat ditegakkan melalui power politik. Pandangan ini dipertegas oleh Ibnu Taymiah yang mengatakan bahwa antara agama dan Negara saling membutuhkan (simbiosis). ${ }^{55}$

${ }^{53}$ Prinsip-prinsip dan nilai-nilai ajaran Islam yang telah dipraktikkan dalam Negara Madinah, diakui atau tidak, ternyata sangat universal dan diakui serta dilaksanakan oleh Negara-negara modern, menurut pengakuan Ernest Gellner, Islam memang agama yang paling cocok untuk modernitas. Lihat, Ernest Gellner, Muslim Society, (Cambridge: Cambridge University Press, 1981), h. 7.

${ }^{54}$ Masykuri Abdillah, "Negara Ideal Menurut Islam dan Implementasinya pada Masa Kini” dalam Komaruddin Hidayat dan Ahmad Gaus AF (ed.), Islam Negara Civil Society Gerakan dan Pemikiran Islam Kontemporer, (Jakarta: Paramadina, 2005), h. 74-75.

${ }^{55}$ Syaikh al-Islām Taqiyuddin Abū Abbas Ahmad bin Abdu al-Halìm bin Abdussalām bin Taimiyyah, as-Siyāsah as-Syar'iyyah, (Beirut: Dār al-Fikr al-Lubnani, 1992), h. 162. 


\section{F. Penutup}

Praktik politik di Negara Madinah, yang dijalankan oleh Nabi Muhammad Saw., merupakan model pembangunan politik egalitarianisme yang sangat kondusif bagi program pemanusiaan manusia dalam Negara dan pemerintahan. Prinsip kesetaraan atau persamaan sesama manusia di depan hukum dan peradilan mempunyai dampak sosial-politik yang signifikan, terutama dalam cara melihat segmen-segmen lain masyarakat politik Indonesia dengan latar belakang pluralistik. Dalam konteks pembangunan politik egalitarianisme, konsep-konsep berbangsa dan bernegara dalam Piagam Madinah dapat memperkuat paham persaudaraan Islam (ukhuwwah Islāmiyyah), yang di dalamnya konsep umat Islam tidak lagi didefinisikan dari segi orientasi dan asosiasi sosial-politik, dan memandang bahwa komunitas umat Islam harus sematamata didasarkan kepada kenyataan bahwa seseorang itu memeluk Islam sebagai agamanya. Sehingga dengan konsep egalitarianisme dapat memperkokoh paham persaudaraan nasional (ukhuwwah wathaniyyah). Bahkan pada levelyang lebih makro, yaitu persaudaraan sesama manusia secara global (ukhuwwah basyariyyah).

Agenda pembangunan politik yang diusung dalam upayaupaya pengejawantahan aspirasi-aspirasi sosial-poliotik Islam adalah pengembangan tatanan-tatanan politik yang egalitarian dan demokratis, serta pengembangan proses-proses ke arah pemerataan ekonomi, melalui optimalisasi pmberdayaan zakat. Dengan demikian, perspektif yang berorientasi nilai, gagasan tentang tatanan politik yang egalitarian atau demokratis mencerminkan prinsip-prinsip dasar politik Islam yang harus diterapkan, yaitu: al-'adl, al-musāwāh dan syūrā, yang mewakili idealisme politik Islam dan tidak akan pernah mengancam kesatuan nasional Indonesia. Bahkan sebaliknya, memberikan nilai positif dan kondusif bagi tercapainya cita-cita politik nasional. []

\section{Daftar Pustaka}

Anders Uhlin, Oposisi Berserak Arus Deras Demokratisasi Gelombang Ketiga di Indonesia, terj. Rofik Suhud, Bandung: Mizan, 1998. 
al-Awwa, Muhammad Salīm, Fi al-Nizām as-Siyāsì li ad-Dawlah alIslāmiyyah, Kairo: Dār asy-Syurūq, 1989.

Baqy, Muhammad Fuad Abdul, Al-Mu'jam al-Mufahras li Alfazh al-Qur'an al-Karim, Indonesia: An-Nasyir Maktabah Dahlan, t.t.

Bahtiar Effendy, Islam dan Negara Transformasi Pemikiran dan Praktik Politik Islam di Indonesia, Jakarta: Paramadina, 1998.

Beetham, David, "Liberal Democracy and the Limits of Democratization", dalam suntingan David Held, Prospects for Democracy North, South. East, West, Cambridge: Polity Press, 1993.

Bellah, Robert N. , Beyond Belief: Essays on Religion in a Post-Traditionalist World, Berkeley and Los Angeles: California University Press, 1991.

Departemen Pendidikan dan Kebudayaan, Kamus Besar Bahasa Indonesia Edisi Kedua, Jakarta: Balai Pustaka, 1995.

Echols, John M. , dan Shadily, Hassan, Kamus Inggris Indonesia, Jakarta: PT. Gramedia Pustaka Utama, 1993.

Encyclopaedia Britannica, London: Encylopaedia Britannica Inc., 1970, vol 21.

al-Farrā,Abū Ya'la Muhammad bin al-Hussein, al-Ahkām as-Sulthāniyah, Beirut: Dār al-Kutub al-Ilmiyah, 1983.

Fazlurrahman, Major Themes of the Qur'an, Minneapolis. Chicago: Bibliotheca Islamica, 1980.

Gellner, Ernest, Muslim Society, Cambridge: Cambridge University Press, 1981.

Grospey, Leo Stratuss Joseph (ed.), History of Political Philosophy, Chicago: 1963.

Grunebaum, G. E. Von, Islam: Essay in The Nature and Growt5h of a Cultural Tradition, London: Routledge and Kegan Paul Ltd, 1969.

Hart, Michael H., The 100, A Ranking of the Most Influential Persons in History, terj. Mahbub Djunaidi, "Teratus Tokoh yang Paling Berpengaruh dalam Sejarah”, Jakarta: Pustaka Jaya, 1986.

Haykal, Muhammad Husin, The Life of Muhammad, translated by Isma'il Ragi al-Faruqi, North American Publication, 1976.

Hefner, Robert W. , Civil Islam: Islam dan Demokrasi di Indonesia, Edisi 
Bahasa Indonesia, Yogyakarta: Institut Studi Arus Informasi ISAI bekerjasama dengan Asia Foundation, 2001.

Hidayat, Komaruddin dan AF, Ahmad Gaus (ed.), Islam Negara Civil Society Gerakan dan Pemikiran Islam Kontemporer, Jakarta: Paramadina, 2005.

Hisyām, Ibn, The Life of Muhammad, a translation of Ishaq's Sirāt arRasul Allah, with introduction and notes by A. Guillaume, Lahore, Karachi, Dacca: Oxford University Press, 1970.

Hornby, A. S. , et. al, The Advanced Learner's Dictionary of Current English, London: Oxford University Press, 1973.

Hitti, Philip K. , Capital Cities of Arab Islam, Minneapolis: University of Minnesota Press, 1966.

Iver, R.M. Mac. , The Modern State, London: Oxford University Press, 1947.

Jurdi, Syarifuddin, Pemikiran Politik Islam Indonesia Pertautan Negara, Khilafah, Masyarakat Madani dan Demokrasi, Yogyakarta: Pustaka Pelajar, 2008.

Imarah, Muhammad, Perang Terminologi Islam Versus Barat, Jakarta: Rabbani Press, 1998.

Jackson, Karl D. and Pye, Lucian W. (eds.), Political Power and Communication in Indonesia, Berkelay, Los Angeles, London: University of California Press, 1978.

Kamaruzzaman, Relasi Islam dan Negara Perspektif Modernis dan Fundamentalis, Magelang: Indonesia Tera, 2001.

Madjid, Nurcholish, Cendikiawan dan Religiusitas Masyarakat, Jakarta: Tabloid Tekad dan Paramadina, 1999.

, Islam Doktrin dan Peradaban, Jakarta: Paramadina dan Dian Rakyat, 2008.

Maula, Tim, Jika Rakyat Berkuasa:Upaya Membangun Masyarakat Madani dalam Kultur Feodal, Bandung: Pustaka Hidayah, 1999.

al-Mawardi, Abū Hasan Ali bin Muhammad bin Habīb al-Bashri, AlAhkām al-Sulthāniyyah fi al-Wilāyāt al-Dīniyyah, Baeirut: Dār alKitāb al-'Arabi, t.t.

Rahardjo, M. Dawam, Ensiklopedia al-Qur'an : Tafsir Sosial Berdasarkan Konsep-konsep Kunci, Jakarta: Paramadina, 1996.

Razak, Abdul, et al (ed.,), Pendidikan Kewargaan (Civil Education); 
Demokrasi, Hak Asasi Manusia dan Masyarakat Madani, Jakarta: ICCE UIN Syarif Hidayatullah dan The Asia Foundation serta Prenada Media, 2003.

Roy , Olivier, Gagalnya Islam Politik, Jakarta: PT Serambi Ilmu Semesta, 1996.

Schmandt, Henry J. , Filsafat Politik Kajian Historis dari Zaman Yunani Kuno Sampai Zaman Modern, Yogyakarta: Pustaka Pelajar, 2005.

Shihab, M. Quraish, Wawasan Al-Qur'an Tafsir Maudu'i atas Pelbagai Persoalan Umat, Bandung: Penerbit Mizan, 1997.

As-Suyuṭi, Al-Imām al-Hafidz Abdurrahmān Jalāluddīn, al-Jāmi' Aṣ- S aghìr fi Ahāđis al-Basyìr an-Nazir, Juz I., Beirut: Dār al-Fikr, tt.

Taimiyyah, Syaikh al-Islām Taqiyuddin Abū Abbas Ahmad bin Abdu al-Halīm bin Abdussalām bin, as-Siyāsah asy-Syar'iyyah, Beirut: Dār al-Fikr al-Lubnani, 1992.

Thaba, Abdul Aziz, Islam dan Negara dalam Politik Orde Baru, Jakarta: Gema Insani Press, 1996.

Tobroni dan Arifin, Syamsul, Islam Pluralisme Budaya dan Politik, Refleksi Teologi Untuk Aksi dalam Keberagamaan dan Pendidikan, Yogyakarta: SI Press, 1994.

Varma, SP. , Teori Politik Modern, Jakarta: PT. RajaGrafindo Persada, 2001.

Watt, W. Montgomery, Muhammad at Medina, Oxford: The Clarendon Press, 1956.

Zaman, Ali Noer, (ed.), Agama untuk Manusia, Yogyakarta: Pustaka Pelajar, 2000. 